Review

\title{
Recent Advances in the Gold-Catalysed Low-Temperature Water-Gas Shift Reaction
}

\author{
James H. Carter *(D) and Graham J. Hutchings * \\ Cardiff Catalysis Institute, School of Chemistry, Cardiff University, Main Building, Park Place, \\ Cardiff CF10 3AT, UK \\ * Correspondence: carterj5@cf.ac.uk (J.H.C.); hutch@cardiff.ac.uk (G.J.H.)
}

Received: 31 October 2018; Accepted: 30 November 2018; Published: 5 December 2018

\begin{abstract}
The low-temperature water-gas shift reaction (LTS: $\mathrm{CO}+\mathrm{H}_{2} \mathrm{O} \rightleftharpoons \mathrm{CO}_{2}+\mathrm{H}_{2}$ ) is a key step in the purification of $\mathrm{H}_{2}$ reformate streams that feed $\mathrm{H}_{2}$ fuel cells. Supported gold catalysts were originally identified as being active for this reaction twenty years ago, and since then, considerable advances have been made in the synthesis and characterisation of these catalysts. In this review, we identify and evaluate the progress towards solving the most important challenge in this research area: the development of robust, highly active catalysts that do not deactivate on-stream under realistic reaction conditions.
\end{abstract}

Keywords: gold; water-gas shift; hydrogen; supported nanoparticles; ceria

\section{Introduction and Scope of Review}

The production of pure hydrogen gas streams is of the upmost importance for the development and implementation of renewable energy solutions based on proton-exchange membrane fuel cells (PEMFCs). The low-temperature water-gas shift reaction (LTS: $\mathrm{CO}+\mathrm{H}_{2} \mathrm{O} \rightleftharpoons \mathrm{CO}_{2}+\mathrm{H}_{2}$ ) has been identified as a key reaction step in reducing the concentration of carbon monoxide in reformate streams [1-5]. The LTS reaction is of particular interest for this application as it generates one mole of $\mathrm{H}_{2}$ for every mole of $\mathrm{CO}$ that is removed. The reaction is moderately exothermic; therefore, the highest equilibrium conversion is achieved at lower temperatures. In order for a PEMFC to operate efficiently, the $\mathrm{CO}$ concentration must be reduced to ppm levels [6] to prevent poisoning of the Pt electrodes. The $\mathrm{CO}$ concentration in the reformate is initially reduced using the high-temperature water-gas shift reaction (HTS) at $300-450{ }^{\circ} \mathrm{C}$, which takes advantage of a higher reaction rate at elevated temperatures. The gas stream is then fed into LTS reactor $\left(200-300{ }^{\circ} \mathrm{C}\right)$, where the $\mathrm{CO}$ concentration must be lowered to $\sim 1 \%$. Finally, the remaining $\mathrm{CO}$ is oxidised in a preferential oxidation of $\mathrm{CO}$ (PROX) reactor before the remaining trace $\mathrm{CO}$ impurities are removed and the $\mathrm{H}_{2}$ is separated for use in the fuel cell. $\mathrm{CO}$ methanation is also sometimes used for the final purification step, as it offers some advantages from the point of view of process integration, despite consuming some $\mathrm{H}_{2}$ in the process. A summary of the hydrogen purification process is presented below in Figure 1.

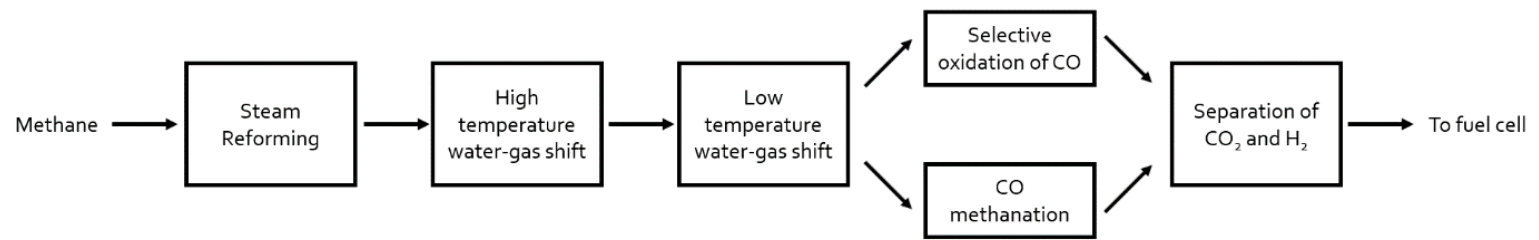

Figure 1. Summary of hydrogen purification process illustrating the role of the low-temperature water-gas shift (LTS) reaction in generating pure hydrogen for proton-exchange membrane fuel cells (PEMFCs). 
Current industrial catalysts for this process are based on $\mathrm{Cu} / \mathrm{ZnO}$ and are typically used to feed $\mathrm{NH}_{3}$ synthesis plants. While stable on-stream, they are less intrinsically active at lower temperature for the LTS reaction than noble metal catalysts [7]. Additionally, these catalysts must be carefully reduced prior to reaction and are pyrophoric once activated. Furthermore, $\mathrm{Cu} / \mathrm{ZnO}$ catalysts typically require low space velocities, which would not be suitable for portable applications [8]. Although there have been significant developments in the performance and understanding of this catalyst in recent years, much attention has been directed towards supported precious metal catalysts, because of their superior low temperature activity and better suitability to localised applications.

Exhaustive reviews on gold-catalysed LTS can be found elsewhere, which cover all aspects of research in this field since the first discoveries. A noteworthy contribution [9] covers the entirety of this field from 1996 to 2014. This review aims to evaluate the recent advances in the field of LTS catalysis using gold. Specifically, the most active catalysts are discussed, but with special consideration of their stability. Furthermore, the recent contributions from computational and fundamental research are also discussed.

\section{Monometallic Catalysts}

\subsection{Gold Supported on Reducible Supports}

The first report of a gold catalyst for the LTS reaction on $\mathrm{Au} / \alpha-\mathrm{Fe}_{2} \mathrm{O}_{3}$ was by Andreeva et al. [10] in 1996. The high activity of $\mathrm{Au} / \mathrm{Fe}_{2} \mathrm{O}_{3}$ was partly ascribed to the reducibility of $\mathrm{Fe}^{3+}$ to $\mathrm{Fe}^{2+}$, which enables the activation of water on the surface, a step that is commonly reported as the rate-determining step over gold catalysts. In contrast, $\mathrm{Au} / \mathrm{TiO}_{2}$ is inactive at low temperatures because of the diminished reducibility of the support [11]. After it was recognised that reducible supports were important for active LTS catalysts and that the water-gas shift reaction proceeded in automotive catalysis, $\mathrm{CeO}_{2}$-based catalysts were extensively studied. Typically metals such as $\mathrm{Pt}$, $\mathrm{Pd}, \mathrm{Rh}, \mathrm{Ni}, \mathrm{Cu}$, and $\mathrm{Au}$ were investigated [12-15]. $\mathrm{Au} / \mathrm{CeO}_{2}$ emerged as the most active of these at low temperatures and has since been the focus of the majority of gold-catalysed LTS investigations. The addition of $\mathrm{Au}$ to $\mathrm{CeO}_{2}$ was found to promote the surface reduction of the metal oxide, enabling $\mathrm{H}_{2}$ spillover and the formation of oxygen vacancies that could activate water and thus facilitate the LTS reaction, but the adsorption strength of $\mathrm{CO}$ on the Au surface is also a key explanation for why it is so active [16].

Although active, $\mathrm{Au} / \mathrm{CeO}_{2}$ was found to be unstable, especially compared with conventional $\mathrm{Cu} / \mathrm{ZnO}$ catalysts. Initial investigations into the deactivation mechanism of $\mathrm{Au} / \mathrm{CeO}_{2}$ revealed that a number of different processes could be relevant, including the accumulation of surface carbonates [17], over-reduction of the support [16,17], and Au particle agglomeration [18]. Recently, Behm and co-workers carried out a time-resolved operando X-ray absorption spectroscopy and diffuse-reflectance infrared Fourier transform spectroscopy (DRIFTS) study to follow the changes that occur to the $\mathrm{Au}$ species during the LTS reaction in the presence of $\mathrm{CO}$ and $\mathrm{H}_{2} \mathrm{O}$ at $180{ }^{\circ} \mathrm{C}$ [19]. The investigation revealed the sensitivity of the catalyst to different pre-treatments and identified sub-nanometre $\mathrm{Au}^{0}$ nanoparticles as the active species. The co-ordination number of Au throughout the reaction did not change and while $\mathrm{Au}^{\delta+}$ was also stable during the reaction, it was found that $\mathrm{Au}^{3+}$ species were short-lived under the reaction conditions. These observations enabled the exclusion of particle agglomeration and oxidation/reduction of the catalyst as contributors to the deactivation mechanism. The accumulation of carbonates was reported to be the primary deactivation mechanism based on DRIFTS measurements, supported by the observation that the catalyst could be regenerated following heat-treatment in $\mathrm{O}_{2}$ at $400{ }^{\circ} \mathrm{C}$.

Hardacre and co-workers reported that the addition of $\mathrm{Zr}$ to $\mathrm{Ce}$ to form a mixed metal oxide support, $\mathrm{CeZrO}_{4}$, resulted in a remarkable increase in catalytic activity compared with $\mathrm{Au} / \mathrm{CeO}_{2}$ [20]. Figure 2 illustrates the activity of the catalyst compared with that of the other supported Au catalysts. In situ extended X-ray absorption fine structure spectroscopy indicated that the active species in 
$\mathrm{Au} / \mathrm{CeZrO}_{4}$ was small metallic $\mathrm{Au}$ nanoparticles, consistent with previous reports that studied $\mathrm{Au} / \mathrm{CeO}_{2}$. The introduction of $\mathrm{Zr}$ to Ce forms a highly defective mixed metal oxide that provides a high concentration of oxygen defect sites, which have two functions; namely to stabilise well-dispersed $\mathrm{Au}$ species and to provide sites for water activation.

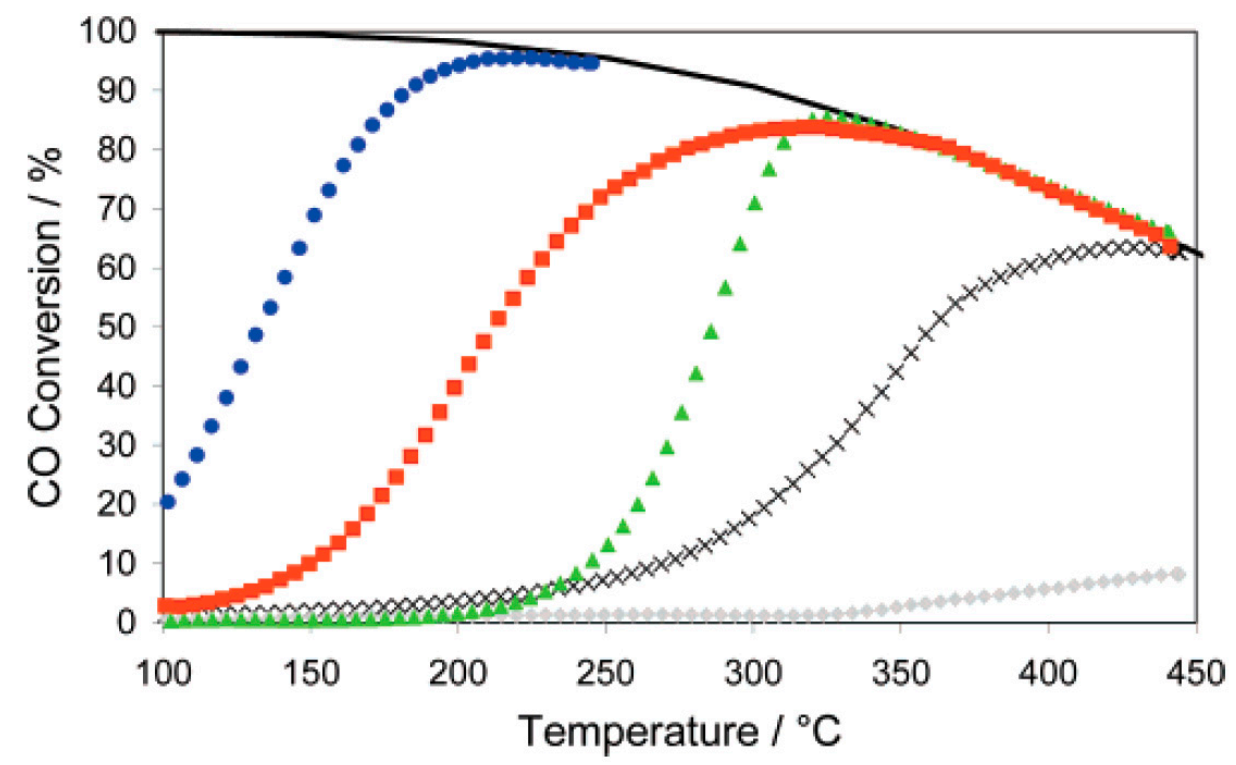

Figure 2. LTS activity of $2 \mathrm{wt} \% \mathrm{Au} / \mathrm{CeZrO}_{4}(\bullet), 0.2 \mathrm{wt} \% \mathrm{Au} / \mathrm{CeZrO}_{4}(\square), 2 \% \mathrm{Au} / \mathrm{CeO}_{2}(\times)$, $2 \% \mathrm{Au} / \mathrm{TiO}_{2}(\diamond)$, and $2 \% \mathrm{Pt} / \mathrm{CeO}_{2}(\Delta)$. LTS reaction conditions: $2.0 \% \mathrm{CO}, 2.5 \% \mathrm{CO}_{2}, 7.5 \% \mathrm{H}_{2} \mathrm{O}$, and $8.1 \% \mathrm{H}_{2}$ in $\mathrm{N}_{2}$. Full line shows equilibrium conversion. Reprinted with permission from the authors of [20]. Copyright 2005 American Chemical Society.

As with the $\mathrm{Au} / \mathrm{CeO}_{2}$ catalyst, $\mathrm{Au} / \mathrm{CeZrO}_{4}$ is susceptible to rapid deactivation under reaction conditions [21,22]. Goguet et al. published a model for the deactivation mechanism using a combination of in situ XPS, in situ CO-DRIFTS, and density functional theory (DFT) calculations [21]. Interestingly, in contrast to $\mathrm{Au} / \mathrm{CeO}_{2}$, it was found that the accumulation of carbonates was not prevalent on the $\mathrm{Au} / \mathrm{CeZrO}_{4}$ catalyst. It was proposed that under reaction conditions, specifically in the presence of high concentrations of water, the gold nanoparticles de-wetted from the support and changed from hemi-spherical to spherical. This significantly reduced the metal-support interface-the proposed active site in this system. A recent investigation into the deactivation mechanism using stop-start STEM and XPS found evidence for particle agglomeration during the reaction, suggesting that the loss of active sites through the sintering of Au was the primary deactivation mechanism [23].

It was recently demonstrated that the LTS reaction could be catalysed over $\mathrm{Au} / \mathrm{CeZrO}_{4}$ using a non-thermal plasma (NTP) rather than through thermo-catalytic activation. The catalyst exhibited remarkably high activity under the NTP at close to room temperature-thermal contributions from the catalyst were accounted for and did not significantly contribute to the observed activity. It was concluded that under the NTP conditions, water was activated in the gas-phase [24]. Such unconventional methods of catalyst activation could be utilised to overcome thermodynamic limitations, as well as potentially stabilise the catalyst, as deactivation rates typically increase with reaction temperature. Moreover, the observation that water is activated in the gas-phase has serious implications for catalyst design; no longer does a reducible support need to be present to activate water. A support such as carbon, which can stabilise atomically-dispersed gold at $200{ }^{\circ} \mathrm{C}$ [25], could anchor well-dispersed, sub-nm Au species and form a stable catalyst. Despite the low reaction temperature, the catalyst still deactivated rapidly, losing ca. $55 \%$ of its activity after $36 \mathrm{~h}$ on-stream, which is similar to the stability of a conventional $\mathrm{Au} / \mathrm{CeZrO}_{4}$ catalyst at $150{ }^{\circ} \mathrm{C}$. The authors observed some particle 
agglomeration based on pre- and post-reaction STEM, which suggests that the deactivation mechanism of the thermally activated and NTP activated catalysts are similar [23].

The addition of $\mathrm{Zr}$ to Ce represents one of the most effective modifications to $\mathrm{Au} / \mathrm{CeO}_{2}$, but there are numerous other elements that have been used to form a mixed metal oxide as a support for the LTS reaction. These include Al [26,27], Fe [28,29], rare earth metals ( $\mathrm{La}, \mathrm{Sm}, \mathrm{Gd}, \mathrm{Yb}, \mathrm{Y}$ ) [30,31], Ga [32], and $\mathrm{Sn}$ [33]. Reina et al. [28] reported the activity and stability of iron-promoted $\mathrm{Au} / \mathrm{CeO}_{2} / \mathrm{Al}_{2} \mathrm{O}_{3}$. Although comparisons with similar supported gold catalysts were not made, the long-term stability of the catalyst was promising; although the catalyst lost ca. $17 \%$ of its initial activity in the first $60 \mathrm{~h}$ of operation under a realistic reformate stream $\left(9 \% \mathrm{CO}, 11 \% \mathrm{CO}_{2}, 30 \% \mathrm{H}_{2} \mathrm{O}, 50 \% \mathrm{H}_{2}\right)$, it maintained this conversion over the next $80 \mathrm{~h}$ on-stream. It should be noted that the reaction was carried out at $330{ }^{\circ} \mathrm{C}$, which is a much higher reaction temperature than typically reported for similar catalysts. Although the Au particle sizes were mostly under $5 \mathrm{~nm}$ (evidenced by the absence of XRD reflections), the actual particle size distribution was not reported, so it is likely that the nanoparticle size was larger than that of the most active catalysts discussed in this review. The deactivation mechanism in this case was reported to be over-reduction of the support, and the enhancement in stability arose from the promotional effect of iron oxide to prevent over-reduction. $\mathrm{ZnO}$ was also reported to promote $\mathrm{Au} / \mathrm{CeO}_{2} / \mathrm{Al}_{2} \mathrm{O}_{3}$ catalysts in a similar manner to the Fe-promoted $\mathrm{Au} / \mathrm{CeO}_{2} / \mathrm{Al}_{2} \mathrm{O}_{3}$ [3]. The use of alumina to support the active $\mathrm{Au} / \mathrm{CeO}_{2}-\mathrm{Fe}_{2} \mathrm{O}_{3}$ component likely contributed to the stability and while the use of such refractory oxides is long-established in industrial LTS catalysts [34], it has not been extensively evaluated in gold catalysts. Indeed, there only a handful of reports that draw on the stability of industrial $\mathrm{Cu}-\mathrm{ZnO}$ catalysts as a starting point for developing novel precious metal supported catalysts. Recently, Santos et al. showed that $\mathrm{Au} / \mathrm{Cu}-\mathrm{ZnO}-\mathrm{Al}_{2} \mathrm{O}_{3}$ were active for the LTS reaction without any activation steps [35]. The catalyst exhibited good on-stream stability at $230{ }^{\circ} \mathrm{C}$, although the catalysts were not compared with conventional supported gold catalysts. The role of the $\mathrm{Au}$ in this context was to facilitate in situ reduction of $\mathrm{Cu}$ species to activate the $\mathrm{Cu}-\mathrm{ZnO}$ component of the catalyst, likely through a hydrogen spillover mechanism. In a similar study, Santos et al. showed that $\mathrm{Au} / \mathrm{Cu}-\mathrm{ZnO}-\mathrm{Al}_{2} \mathrm{O}_{3}$ exhibited good stability under start-up/shutdown cycles, an important experiment that involves the heating and cooling of the reactor to induce condensation of water on the catalyst bed [36]. While this is often overlooked as a means of catalyst evaluation, it represents one of the most effect methods of assessing the stability of LTS catalysts for portable applications. Interestingly, in a comparison of gold-promoted $\mathrm{Cu} / \mathrm{Al}_{2} \mathrm{O}_{3}$ catalysts, it was found that the addition of $\mathrm{CeO}_{2}$ significantly enhanced the start-up/shutdown stability of the catalyst [36,37]. After four cycles, the $\mathrm{Au} / \mathrm{Cu}$ - $\mathrm{Al}$ catalyst exhibited approximately $75 \%$ of its initial activity, whereas the $\mathrm{CeO}_{2}$-containing catalyst maintained its initial activity. Unfortunately, investigating the origin of the catalyst stability was beyond the scope of this work, but such an investigation would be of great interest to the catalyst community. In fact, the deactivation mechanism under start-up/shutdown conditions has not been thoroughly investigated.

The morphology of $\mathrm{CeO}_{2}$ has also been studied, which includes reports on nanorods $[38,39]$ and mesoporous $\mathrm{CeO}_{2}$ [40]. Ta et al. [39] reported that $\mathrm{Au} / \mathrm{CeO}_{2}$ nanorods exhibit enhanced stability during the LTS reaction (and CO oxidation), losing only $\sim 6 \%$ conversion over $40 \mathrm{~h}$ on-stream. The mechanism of stabilisation was also studied using environmental TEM (ETEM) and it was concluded that $2 \mathrm{~nm}$ Au nanoparticles were strongly anchored because of their intimate contact with the support oxygen vacancies, which formed a buried interface with the Au nanoparticle. On the other hand, the authors also reported that particle agglomeration occurred on sub-nm Au species during the reaction; such species could be highly active and stabilising these species would be the ultimate goal. While the overall stability is promising, the reaction feed consisted of $3 \% \mathrm{CO}$ and $9 \% \mathrm{H}_{2} \mathrm{O} / \mathrm{N}_{2}$; it has been shown that the reaction feed, in particular the concentration of $\mathrm{H}_{2} \mathrm{O}$ and $\mathrm{CO}_{2}$, can strongly affect catalyst stability [21]. Additionally, reversible deactivation through over-reduction has been previously observed in $\mathrm{Au} / \mathrm{CeO}_{2}$ catalysts [17]. A realistic reformate stream would contain a high 
concentration of $\mathrm{H}_{2}$, as well as $\mathrm{CO}_{2}$, so it is unclear if similar catalyst stability would be observed under these conditions.

In recent years, a new class of heterogeneous catalysts has emerged: atomically-dispersed supported metal catalysts. These have been reported to catalyse a number of reactions, including CO oxidation and the LTS reaction, and are of interest for many reasons, not least because of their efficient use of precious metal. Flytzani-Stephanopoulos and co-workers were the first to clearly demonstrate the activity of atomically-dispersed $\mathrm{Au}$ on various reducible supports. In a recent conspectus, Flytzani-Stephanopoulos summarised the evidence for the active site of Au catalysts being atomically-dispered $\mathrm{Au}$ in the LTS reaction [41]. Using a cyanide leaching method ( $\mathrm{CN}^{-}$leaching), the removal of metallic $\mathrm{Au}$ species was achieved, leaving only cationic, atomically-dispersed $\mathrm{Au}$ on the support. Figure 3 summarises the activity of various supported Au catalysts, after $\mathrm{CN}^{-}$ leaching. The correlation in this Arrhenius plot strongly suggests a common active site, suggested to be $\mathrm{Au}-\mathrm{O}_{\mathrm{x}}(\mathrm{OH})-\mathrm{S}$ site, where $\mathrm{S}$ is the support. However, it is extremely difficult to prove that only atomically-dispersed species are the active site, and the stability of these species under LTS reaction conditions is known to be short-lived [20,23]. Therefore, excluding the contribution from oligomers, clusters, and other sub-nm species is difficult.

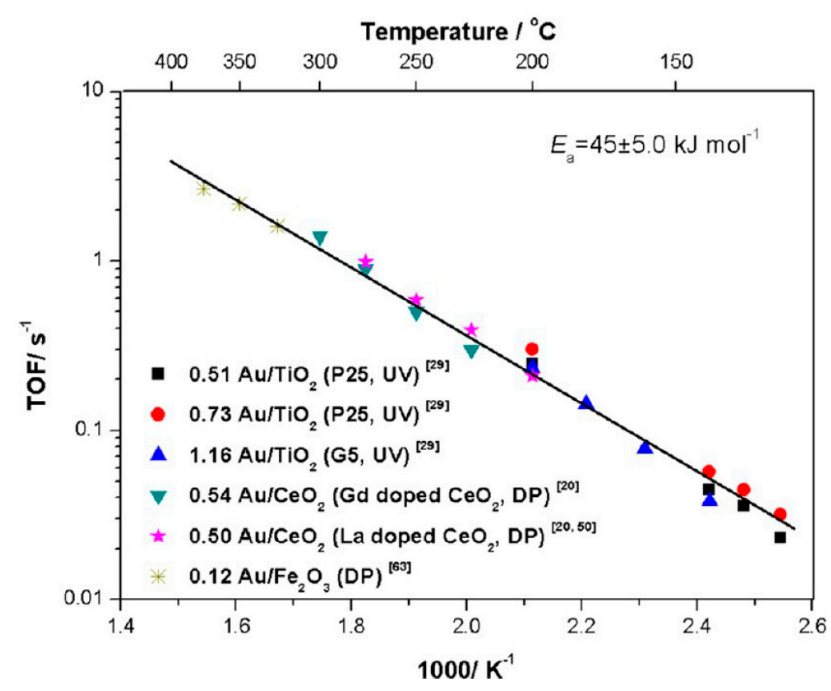

Figure 3. Turnover frequency of various cyanide leached $\mathrm{Au}$ catalysts prepared by deposition-precipitation (DP) or UV-assisted DP (UV). Eleven percent $\mathrm{CO}, 26 \% \mathrm{H}_{2} \mathrm{O}, 7 \% \mathrm{CO}_{2}, 26 \% \mathrm{H}_{2}$, He. The numbers represent the weight percentage of $\mathrm{Au}$ in each sample. Reprinted with permission from the authors of [41]. Copyright American Chemical Society 2014.

\subsection{Gold Supported on Non-Reducible Supports}

It is generally accepted that reducible supports are a pre-requisite for an active LTS catalyst, because of their facility to activate water. Non-reducible supports such as carbon, $\mathrm{Al}_{2} \mathrm{O}_{3}$, and $\mathrm{SiO}_{2}$, in contrast to $\mathrm{CeO}_{2}$ or $\mathrm{Fe}_{2} \mathrm{O}_{3}$, cannot participate in the reaction in this way, and thus are much less active [42-44]. However, this convention has recently been challenged by the discovery of active LTS catalysts that do not rely on reducible metal oxide supports.

Flytzani-Stephanopoulos and co-workers reported that atomically-dispersed $\mathrm{Au}$, supported on MCM-41 or potassium-Linde type L (KLTL) zeolite and promoted by Na or K ions, catalysed the LTS reaction [45]. The active site was reported to exist as ensembles of $\mathrm{Au}-\mathrm{O}-\mathrm{OH}_{\mathrm{x}}-\mathrm{Na}$ or $\mathrm{Au}-\mathrm{O}-\mathrm{OH}_{\mathrm{x}}-\mathrm{K}$, and the intrinsic activity was measured to be the same as other atomically-dispersed Au catalysts, regardless of the reducibility of the support. Although direct comparisons were not made between this catalyst and the conventional $\mathrm{Au} / \mathrm{CeO}_{2}$-based catalysts, the significance of this work was the discovery that the activation of water could be achieved without a reducible support, using abundant elements such as $\mathrm{Na}$ or K. Furthermore, it confirmed that atomically-dispersed Au species, thought to co-exist 
with nanoparticles on conventional catalysts, were catalytically active for the LTS reaction. Additionally, despite some deactivation over $100 \mathrm{~h}$ on-stream in a realistic reformate mixture, the Au-K/KLTL catalyst retained ca. $77 \%$ of its initial activity.

Transition metal carbides have been identified as having similar properties as platinum group metals [46-48], although their application as a support in catalysis has been limited compared with metal oxides. Ribeiro and co-workers first reported that $\mathrm{Pt}, \mathrm{Au}, \mathrm{Pd}$, and $\mathrm{Ni}$ supported on $\mathrm{Mo}_{2} \mathrm{C}$ were 4-8 times more active per surface area than the commercial $\mathrm{Cu} / \mathrm{ZnO} / \mathrm{Al}_{2} \mathrm{O}_{3}$ catalyst at $120^{\circ} \mathrm{C}$. The active site was concluded to be the same as that of conventional $\mathrm{Au} / \mathrm{CeO}_{2}$ catalysts, that is, the metal-support interface. Ma and co-workers recently discovered that the phase and structure of the $\mathrm{Mo}_{2} \mathrm{C}$ was crucial to high catalytic activity. In the initial report from Ribeiro and co-workers, $\beta-\mathrm{Mo}_{2} \mathrm{C}$ was used as the support. However, when $\alpha-\mathrm{MoC}$ was used, the activity of the resultant supported $\mathrm{Au}$ catalyst was dramatically improved. The origin of the high catalytic activity was concluded to be the facile activation of water, which was observed at temperatures as low as $303 \mathrm{~K}$. The initial activity of $2 \% \mathrm{Au} / \alpha-\mathrm{MoC}$ represents one of, if not the most, active LTS catalyst reported to date, although the on-stream stability is poor; after $100 \mathrm{~h}$ on-stream, the catalyst retained only $60 \%$ of its initial activity. In a similar study that demonstrated one of the first reports of strong-metal support interaction (SMSI) between metals and non-oxides, Dong et al. showed that $\mathrm{Au} / \mathrm{MoC}_{\mathrm{x}}$ could be formed after treatment of $\mathrm{Au} / \mathrm{MoO}_{3}$ with $\mathrm{CH}_{4} / \mathrm{H}_{2}$ at $700{ }^{\circ} \mathrm{C}$ [49]. The authors demonstrated that the $\mathrm{Au} / \mathrm{MoC}_{\mathrm{x}}$ catalyst could undergo reversible aggregation-redistribution processes upon cycled calcination-carbonization treatment only, and the $\mathrm{Au} / \mathrm{MoC}_{\mathrm{x}}$ exhibited high activity for the LTS reaction (Figure 4). However, it lost $20 \%$ of its original activity in the first $4 \mathrm{~h}$ on-stream at $180{ }^{\circ} \mathrm{C}$ in a feed containing $3 \% \mathrm{CO}$ and $10 \% \mathrm{H}_{2} \mathrm{O}$. Although the catalyst could be regenerated in $20 \% \mathrm{CH}_{4} / \mathrm{H}_{2}$ at $600{ }^{\circ} \mathrm{C}$, its feasibility in fuel cell application is clearly limited by this regeneration step. SMSI effects on oxide-supported $\mathrm{Au}$ nanoparticles have only been recently demonstrated [50]; previously, it was thought that the work function and surface energy of $\mathrm{Au}$ were too low [51]. $\mathrm{Au} / \mathrm{TiO}_{2}$ catalysts were prepared by deposition-precipitation and after the SMSI effect was induced through chemical reduction at elevated temperature, the catalyst exhibited enhanced on-stream stability during $\mathrm{CO}$ oxidation. Although this catalyst would not be expected to be active for the LTS reaction, if a similar SMSI effect could be achieved on $\mathrm{Fe}_{2} \mathrm{O}_{3}$ or $\mathrm{CeO}_{2}$, an active and stable LTS catalyst could be the result.
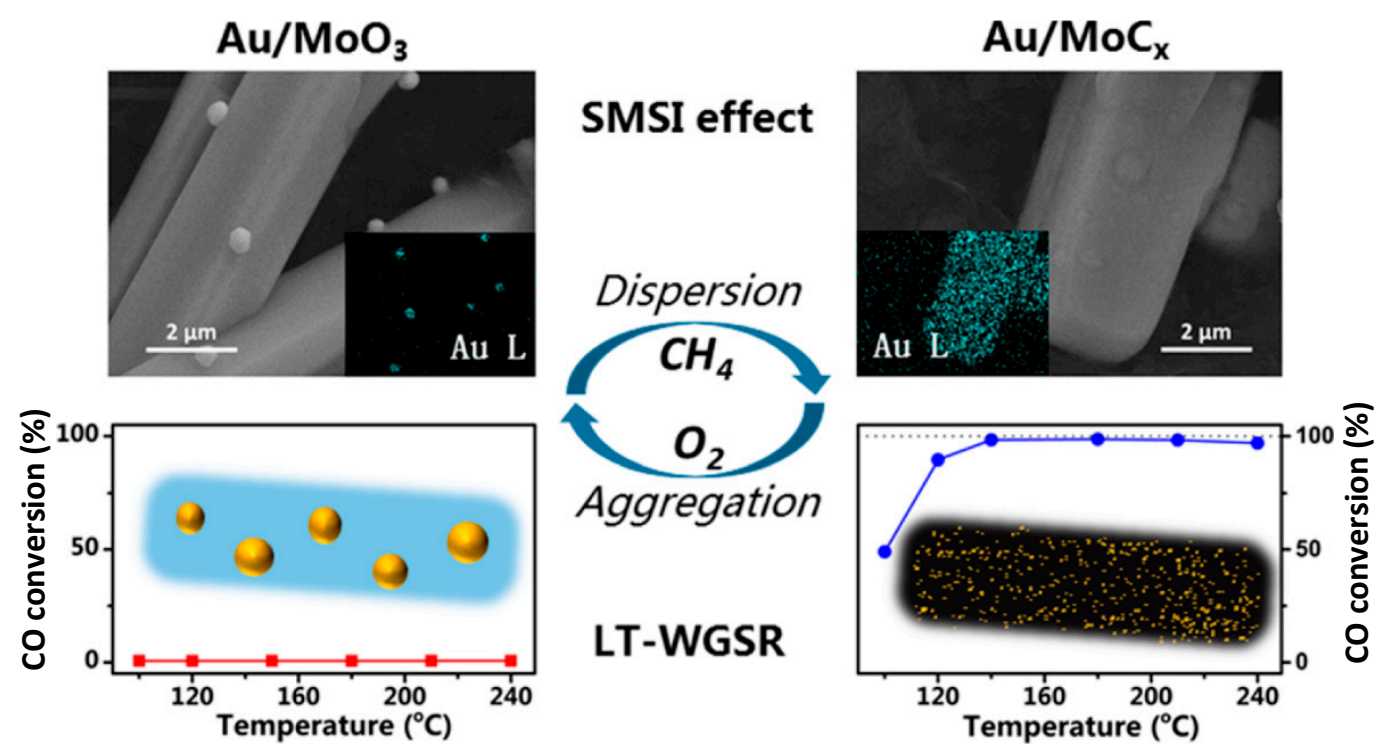

Figure 4. Summary of the reversibility of the $\mathrm{Au} / \mathrm{MoO}_{3}$ (left) and $\mathrm{Au} / \mathrm{MoC}_{\mathrm{x}}$ (right) phases, showing the difference in dispersion (top) and catalyst activity (bottom) in the low-temperature water-gas shift reaction (LT-WGS). Adapted with permission from the authors of [49]. Copyright 2018 American Chemical Society. SMSI-strong-metal support interaction. 
$\mathrm{Li}$ and co-workers recently reported that it was possible to create oxygen vacancies on the surface of $\mathrm{ZrO}_{2}$ by etching the oxygen with hydrogen. When gold was supported on this modified $\mathrm{ZrO}_{2}$, it was active for the LTS reaction [52]. Typically, $\mathrm{Au} / \mathrm{ZrO}_{2}$ exhibits poor LTS activity and even when promoted by sulfating the support, the resultant catalyst does not compete with catalysts supported on reducible metal oxides. This etching technique was successfully applied to conventionally prepared $\mathrm{TiO}_{2}$ [53] and $\mathrm{TiO}_{2}$ nanoribbons [54]. The enhancement in catalytic activity upon the introduction of oxygen vacancies is further evidence of the importance of the efficient activation of water and illustrates why non-reducible oxide supports typically exhibit low activity.

\section{Bimetallic Catalysts}

Despite the high activity of gold catalysts, as discussed above, the poor long-term on-stream stability of these catalysts has prevented any prospect of commercialisation. One strategy that has been explored to enhance the catalyst stability is the introduction of a second supported metal to form a bimetallic nanoparticle. There are relatively few examples of bimetallic Au catalysts for the LTS reaction, which is surprising given the large number of studies on liquid phase oxidation reactions [55-57].

The earliest examples of bimetallic gold catalysts for the LTS reaction were by Venugopal et al. [58,59]. The authors examined $\mathrm{Au} / \mathrm{M} / \mathrm{Fe}_{2} \mathrm{O}_{3}$ catalysts where $\mathrm{M}=\mathrm{Ag}, \mathrm{Bi}, \mathrm{Co}, \mathrm{Cu}, \mathrm{Mn}$, $\mathrm{Ni}, \mathrm{Pb}, \mathrm{Ru}, \mathrm{Sn}$, or $\mathrm{Tl}$. The catalysts were calcined at $400{ }^{\circ} \mathrm{C}$ and many of the bimetallic catalysts tested were reported to be more active than the unmodified gold catalyst, with $\mathrm{Au}-\mathrm{Ru}, \mathrm{Au}-\mathrm{Ni}$, and $\mathrm{Au}-\mathrm{Bi}$ exhibiting the highest reaction rates. At $120^{\circ} \mathrm{C}$, the $\mathrm{CO}$ conversion of $\mathrm{Au}-\mathrm{Ru}$ was three times that of $\mathrm{Au} / \mathrm{Fe}_{2} \mathrm{O}_{3}$. It is worth noting that the catalysts were calcined at $400{ }^{\circ} \mathrm{C}$, in contrast to the most active class of gold catalysts, which are not generally calcined at such high temperatures, where particle agglomeration would be expected. The authors stated that they expect the gold nanoparticles to be greater than $10 \mathrm{~nm}$, evidenced by TEM and the detection of Au reflections in XRD analysis, which significantly limits meaningful comparisons between these catalysts and the most active ones supported on $\mathrm{CeO}_{2}$-based supports or $\mathrm{MoC}$. It is interesting, however, that the authors observed an increased thermal stability in the $\mathrm{Au} / \mathrm{Ru} / \mathrm{Fe}_{2} \mathrm{O}_{3}$ compared with either of the monometallic catalysts.

Tsang and co-workers prepared $\mathrm{Au} / \mathrm{Pd} / \mathrm{CeO}_{2}$ and $\mathrm{Au} / \mathrm{Pt} / \mathrm{CeO}_{2}$ by co-precipitation and also calcined the catalysts at $400{ }^{\circ} \mathrm{C}$ [60]. They reported the particle size of the monometallic gold to be $22 \mathrm{~nm}$. In the bimetallic catalysts, particularly $\mathrm{Au} / \mathrm{Pt} / \mathrm{CeO}_{2}$, the particle size was smaller and greater activity was reported. This investigation did not compare the bimetallic catalysts with the most active monometallic gold catalysts, but they would not be expected to be as active, given the large particle size. Suo and co-workers later compared a range of $\mathrm{Au} / \mathrm{M} / \mathrm{CeO}_{2}$ (where $\mathrm{M}=\mathrm{Ni}, \mathrm{Cu}, \mathrm{Ag}, \mathrm{Pt}$, or $\mathrm{Pd}$ ). While many of the bimetallic catalysts were less active than $\mathrm{Au}$ at 200 and $250{ }^{\circ} \mathrm{C}$, Au/Pt exhibited a significant increase in $\mathrm{CO}$ conversion. The authors cited the modification of the $\mathrm{CeO}_{2}$ support, which contained more oxygen vacancies, and the stabilisation of $\mathrm{Au}^{\delta+}$ in the bimetallic catalyst as the reasons for the observed activity enhancement. Unfortunately, the particle size distribution was not reported and so it is unclear how this varied between the series of catalysts. The reaction mechanism of the LTS reaction is known to be highly sensitive to reaction temperature and the composition of the reactant gases [61] and so it not known whether the $\mathrm{Au} / \mathrm{Pt}$ catalysts would be more active than $\mathrm{Au}$ at lower temperatures $\left(120-150{ }^{\circ} \mathrm{C}\right)$. In fact, in a comparative study between Au and Pt for the LTS reaction, Castaño et al. showed that $\mathrm{Au}$ was more active than $\mathrm{Pt}$ at lower temperatures, whereas $\mathrm{Pt}$ was more active at higher temperatures [62].

Recently, an investigation into $\mathrm{Au} / \mathrm{Pd}$ catalysts for the LTS reaction was carried out whereby a series of different $\mathrm{Au} / \mathrm{Pd}$ molar ratio nanoparticles were supported on $\mathrm{CeZrO}_{4}$ [63]. An anti-synergetic relationship was observed whereby many of the bimetallic AuPd catalysts were found to be less active than the monometallic Au or Pd counterparts. The origin of the anti-synergy was concluded to be based on the increased metal nanoparticle size, which decreased the metal-support interface and, therefore, the number of active sites on the catalyst. There was also no enhancement in catalyst stability after 
$16 \mathrm{~h}$ on-stream in any of the bimetallic catalysts. Additionally, it has been shown that CO preferentially binds to Pd over Au, which could potentially passivate the Au [64,65]. These findings are in contrast to an earlier DFT study that predicted $\mathrm{Au} / \mathrm{Pd}$ catalysts to be highly active for the LTS reaction. Saqlain et al. modelled the Pd/ $\mathrm{Au}$ (100) surface and its efficacy in the LTS reaction [66]. According to their calculations, Pd segregation under a $\mathrm{CO}$ environment is favoured and the subsequent Pd-rich surface can easily activate water and $\mathrm{CO}$, which should result in an active catalyst. The discrepancy in the prediction and the experimental data reported is likely a consequence of the complex and inhomogeneous nature of prepared catalysts and the specific surface that was modelled; the properties of (100) metal surfaces would be expected to be very different from supported hemi-spherical or icosahedral nanoparticles that would comprise a typical catalyst prepared by deposition-precipitation.

Overall, the progress on bimetallic catalysts for the LTS reaction has been limited. In the reports that detail synergetic effects of alloying $\mathrm{Au}$, the studies are often not comparable with the most active monometallic catalysts. Additionally, there is no evidence that bimetallic catalysts are more stable than a monometallic Au catalyst, although this aspect of catalyst performance has often been overlooked. The absence of many reports on supported bimetallic LTS catalysts likely reflects the fact that the introduction of a secondary metal to Au results in a less active catalyst.

\section{Mechanistic and Fundamental Studies}

Two reaction mechanisms have been proposed for the water-gas shift reaction; namely the redox mechanism and the associative mechanism. The redox or regenerative mechanism involves the oxidation of $\mathrm{CO}$ by $\mathrm{O}$ on the surface of the catalyst to form $\mathrm{CO}_{2}$. The support is then re-oxidised by $\mathrm{H}_{2} \mathrm{O}$ and forms $\mathrm{H}_{2}$ as a result [67-69]. This reaction pathway is generally thought to occur at higher temperatures $[18,69,70]$ and is thus not relevant to the gold-catalysed LTS reaction. The associative mechanism, in contrast, takes into account reaction intermediates, although the actual structure of the intermediate is still debated. Two intermediates are commonly proposed as key reaction intermediates: carboxyl and formate. Figure 5 illustrates the difference in structure between the two intermediates and is not intended as a comprehensive depiction of the reaction pathway. In both reaction mechanisms, $\mathrm{CO}$ adsorbs the periphery of an $\mathrm{Au}$ nanoparticle and $\mathrm{H}_{2} \mathrm{O}$ dissociates on the support, in the case of $\mathrm{CeO}_{2}$-based supports, in an oxygen vacancy. In branch (a), a carboxyl intermediate is formed from the addition of $\mathrm{OH}_{(\text {ads })}$ to a $\mathrm{CO}_{(\mathrm{ads})}$ molecule. This decomposes into $\mathrm{CO}_{2}$, leaving two $\mathrm{H}_{(\text {ads })}$ species that combine to form $\mathrm{H}_{2}$ and desorb into the gas-phase [68]. In contrast, branch (b) proceeds via a formate, which can be formed after the insertion of $\mathrm{CO}$ into the $\mathrm{O}-\mathrm{H}$ bond of dissociated water, although it has also been proposed that can be formed via the addition of $\mathrm{H}$ to $\mathrm{CO}$ on the surface of a metal nanoparticle [71]. Subsequently, $\mathrm{CO}_{2}$ is formed after the oxidation of this species by another $\mathrm{OH}_{(\mathrm{ads})}$ species and, finally, $\mathrm{H}_{2}$ is formed. The formate intermediate is depicted as being adsorbed on an $\mathrm{Au}$ site, but it can be formed on the catalyst support.

While there have been many studies that conclude a formate (HCOO) intermediate is significant [70,72-74], there have also been reports to the contrary; Meunier and co-workers measured the rate of $\mathrm{CO}_{2}$ formation and the rate of formate decomposition and showed that the rates were considerably different, suggesting that it was not important in the main reaction pathway [75]. Burch critically reviewed the evidence for and against a formate mechanism and concluded that it was only of minor importance [61]. It was also noted that the predominant LTS mechanism was highly dependent on the experimental conditions used in the study. 


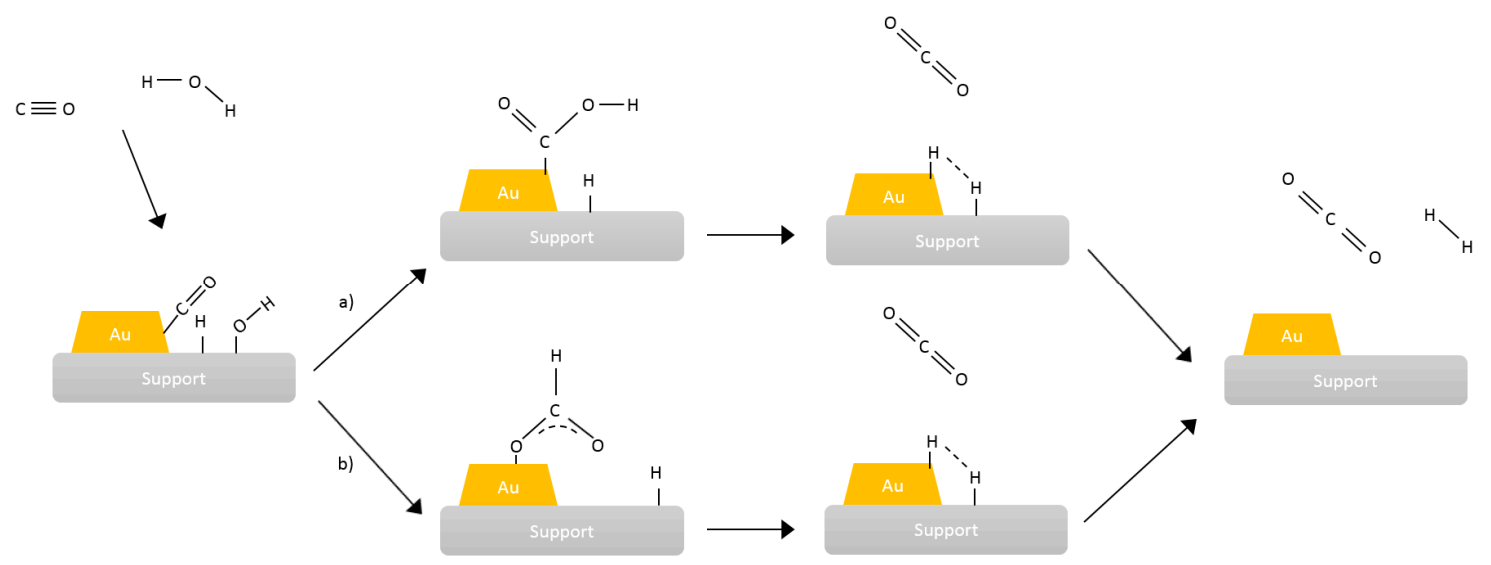

Figure 5. Summary of (a) carboxyl- and (b) formate-mediated reaction mechanisms in the LTS reaction. The Au particle and support in the schematic are to indicate the position of surface sites only.

In a discussion of the possible reaction mechanisms of the gold-catalysed WGS reaction, Bond [68] noted the similarity between the LTS reaction and formic acid decomposition (FAD). It was suggested that both reactions could proceed through the same carboxyl intermediate $(-\mathrm{COOH})$, making FAD a simple test reaction for WGS activity. This hypothesis was based on the similar activation energies observed on $\mathrm{Au} / \mathrm{SiO}_{2}$ and $\mathrm{Au} / \mathrm{Al}_{2} \mathrm{O}_{3}$ for both reactions between 100 and $300{ }^{\circ} \mathrm{C}$. Other researchers have also identified the similarities between the LTS reaction and FAD. Davis and co-workers examined $\mathrm{Pt} / \mathrm{CeO}_{2}$ catalysts for both reactions and identified a common intermediate on these catalysts: a bidentate formate [76]. A recent study showed that in a series of bimetallic AuPd/CeZrO $\mathrm{Cratalysts}_{4}$ with different $\mathrm{Au} / \mathrm{Pd}$ ratios, the monometallic $\mathrm{Au}$ and $\mathrm{Pd}$ catalysts were more active than some of the bimetallic AuPd catalysts for LTS, FAD, and CO oxidation [63]. In contrast, for benzyl alcohol oxidation, a synergistic relationship was identified whereby the bimetallic catalysts were much more active than the monometallic ones. This is shown in Figure 6. The common activity trend observed for the LTS, FAD, and CO oxidation suggests that in each reaction, a common active site is required and catalysts that are active for either FAD or CO oxidation could also be active for the LTS reaction.

Burch proposed a universal mechanism, taking into account the evidence for the redox and associative mechanism, as well as resolving the conflicting reports in the literature [71]. It was recognised that the reaction mechanism is heavily influenced by the reaction conditions and the various equilibria that control the stability of formates, carboxylates, or carbonates on the surface. For example, at high $\mathrm{H}_{2} \mathrm{O} / \mathrm{CO}_{2}$ ratios, where surface $\mathrm{OH}$ groups dominate, formates would be expected, while at low $\mathrm{H}_{2} \mathrm{O} / \mathrm{CO}_{2}$ ratios, where surface carbonates are prevalent, formate formation would be inhibited. This observation no doubt explains some of the discrepancies reported in the literature.

Many insights into the mechanism of the LTS reaction over Au catalysts have been made through studying model catalysts composed of $\mathrm{Au}$ on a metal oxide or mixed metal oxide, most notably by Rodriguez and co-workers. In addition to conventional metal/oxide systems, they have studied inverse systems whereby a metal oxide such as $\mathrm{CeO}_{\mathrm{x}}$ is supported on an $\mathrm{Au}$ substrate. These experiments provide an interesting perspective on the role of the metal-support interface. Two reviews of this work have very recently been published and will therefore not be discussed in detail in this review [1,77]. Rodriguez and co-workers also studied the reaction mechanism over non-oxidic supports, specifically Au/TiC. Using model studies combined with DFT calculations, they reported that $\mathrm{Au} / \mathrm{TiC}$ is highly active for the LTS reaction and calculated that the reaction proceeds via a formate intermediate. However, an experimental investigation on this catalyst has not yet been carried out. 


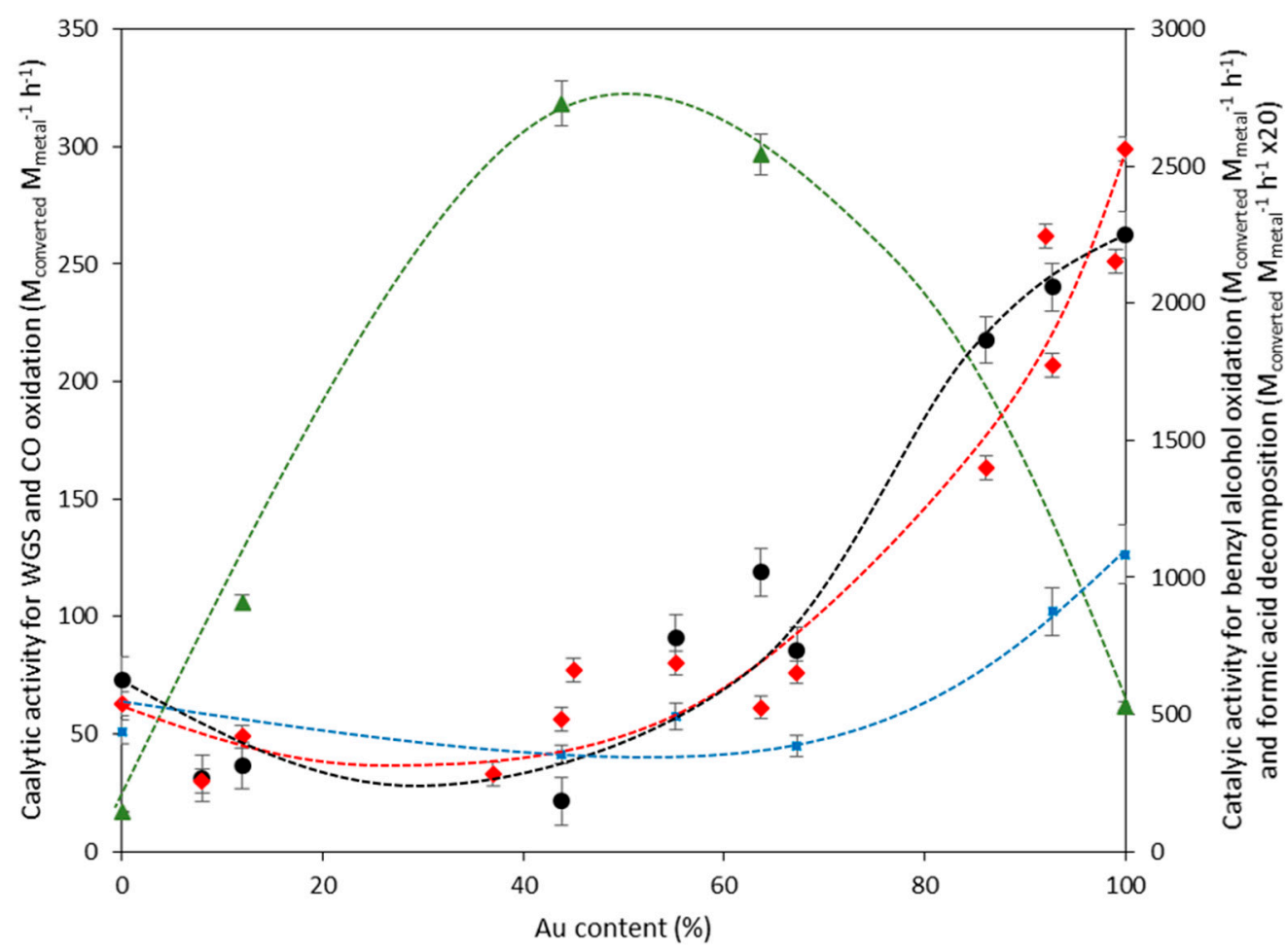

Figure 6. Catalytic activity of various AuxPdy/CeZrO 4 catalysts for the water-gas shift $(\bullet)$; CO oxidation ( $\bullet$ ); formic acid decomposition ( $\square$ ); and benzyl alcohol oxidation ( $\triangle$ ). Activity measurements were recorded after $1 \mathrm{~h}$ on stream at $150{ }^{\circ} \mathrm{C}\left(2 \% \mathrm{CO}, 2 \% \mathrm{H}_{2} \mathrm{O}, 7.5 \% \mathrm{H}_{2} \mathrm{O}\right.$, $8.1 \% \mathrm{H}_{2}$ ) gas-hourly space velocity $(\mathrm{GSHV})=52,000 \mathrm{~h}^{-1}$. Reproduced with permission from the authors of [63]. Copyright American Chemical Society 2017.

There have been many contributions to understanding LTS chemistry from computational researchers. Many of these studies involve the prediction of active catalysts based on DFT calculations that predict low energy barriers for certain reaction steps such as water dissociation, which is often cited as the rate-determining step [77,78]. Examples of catalysts that have been predicted to be active include bimetallic $\mathrm{Au}-\mathrm{Pd}[66]$ and $\mathrm{Au}-\mathrm{Cu}$ [79], although the applicability of these studies to supported metal catalysts is limited by their negligence of the role of the support in the reaction.

Recently, Greenley and co-workers demonstrated the importance of the metal-support interface in the LTS reaction using a combined DFT, microkinetic, and experimental investigation into $\mathrm{Au} / \mathrm{MgO}$ for the LTS reaction. The calculated energy barrier for water dissociation on Au was very high $(\sim 2 \mathrm{eV})$, whereas at the $\mathrm{Au} / \mathrm{MgO}$ interface, it was essentially zero. Additionally, the reaction pathway and intermediates were calculated using an $\mathrm{Au}$ nanowire on $\mathrm{MgO}$ (100) substrate as the model. It was found that the reaction proceeded through a carboxyl intermediate.

\section{Conclusions and Outlook}

This review has described the latest advances in LTS catalysis using gold with an emphasis on catalyst stability. The mostly widely studied catalyst is gold supported on ceria or a mixed ceria-based mixed metal oxide. Although debate continues regarding the predominant deactivation mechanism of this catalyst during the reaction, the more important fact remains that all of these catalysts lose a significant proportion of their initial activity after a few hours on-stream. This is no doubt the result of the nature of the active species: sub-nm clusters and small nanoparticles that are intrinsically unstable when conventionally supported on a metal oxide. While interest in gold-catalysed LTS has remained strong since its initial discovery as an active catalyst, development of a commercially viable catalyst has not yet taken place. There are many reports that demonstrate highly active catalysts for the LTS reaction, but activity is not the barrier to commercialisation; it is more pertinent to develop robust catalysts 
that can operate for weeks on-stream without significant deactivation. While more active catalysts may be able to operate at lower temperatures and consequently deactivate more slowly, even the most active catalysts still lose significant activity after a few hours on-stream at $120-150{ }^{\circ} \mathrm{C}$. The challenge of stabilising highly active supported Au species is compounded by the recent discoveries that the most active species, formed of sub-nm clusters, are also likely to be the least stable. It is promising that new and unexpected catalyst systems are emerging, such as the application of non-reducible supports, atomically-dispersed gold, and catalyst activation using non-thermal plasmas, but there is still much progress needed before this type of catalyst could be considered for its practical application. Recent examples of classical SMSI effects on supported gold catalysts for other reactions should serve as incentives to investigate such nanostructures on reducible oxides in the context of the LTS reaction.

Author Contributions: Writing—original draft preparation, J.H.C; writing—review and editing, G.J.H.

Funding: The authors acknowledge funding from the European Research Council ("After the Goldrush" ERC-2011-AdG-291319).

Conflicts of Interest: The authors declare no conflicts of interest.

\section{References}

1. Rodriguez, J.A.; Grinter, D.C.; Liu, Z.Y.; Palomino, R.M.; Senanayake, S.D. Ceria-based model catalysts: Fundamental studies on the importance of the metal-ceria interface in CO oxidation, the water-gas shift, $\mathrm{CO}_{2}$ hydrogenation, and methane and alcohol reforming. Chem. Soc. Rev. 2017, 46, 1824-1841. [CrossRef] [PubMed]

2. Ilieva, L.; Petrova, P.; Ivanov, I.; Munteanu, G.; Boutonnet, M.; Sobczac, J.W.; Lisowski, W.; Kaszkur, Z.; Markov, P.; Venezia, A.M.; et al. Nanosized gold catalysts on Pr-modified ceria for pure hydrogen production via WGS reaction. Mater. Chem. Phys. 2015, 157, 138-146. [CrossRef]

3. Ramirez Reina, T.; Ivanova, S.; Jose Delgado, J.; Ivanov, I.; Idakiev, V.; Tabakova, T.; Angel Centeno, M.; Antonio Odriozola, J. Viability of $\mathrm{Au} / \mathrm{CeO}_{2}-\mathrm{ZnO} / \mathrm{Al}_{2} \mathrm{O}_{3}$ Catalysts for Pure Hydrogen Production by the Water-Gas Shift Reaction. Chemcatchem 2014, 6, 1401-1409. [CrossRef]

4. Barakat, T.; Rooke, J.C.; Genty, E.; Cousin, R.; Siffert, S.; Su, B.L. Gold catalysts in environmental remediation and water-gas shift technologies. Energy Environ. Sci. 2013, 6, 371-391. [CrossRef]

5. Maciel, C.G.; Silva, T.d.F.; Assaf, E.M.; Assaf, J.M. Hydrogen production and purification from the water-gas shift reaction on $\mathrm{CuO} / \mathrm{CeO}_{2}-\mathrm{TiO}_{2}$ catalysts. Appl. Energy 2013, 112, 52-59. [CrossRef]

6. Ralph, T.R.; Hogarth, M.P. Catalysis for Low Temperature Fuel Cells. Platin. Met. Rev. 2002, 46, 146.

7. Yao, S.Y.; Zhang, X.; Zhou, W.; Gao, R.; Xu, W.Q.; Ye, Y.F.; Lin, L.L.; Wen, X.D.; Liu, P.; Chen, B.B.; et al. Atomic-layered Au clusters on alpha-MoC as catalysts for the low-temperature water-gas shift reaction. Science 2017, 357, 389-393. [CrossRef] [PubMed]

8. Ratnasamy, C.; Wagner, J.P. Water Gas Shift Catalysis. Catal. Rev. Sci. Eng. 2009, 51, 325-440. [CrossRef]

9. Ramirez Reina, T.; González, M.; Sandra, P.; Ivanova, S.; Odriozola, J.A. Twenty years of golden future in the Water Gas Shift Reaction. In Heterogeneous Gold Catalysts and Catalysis; Ma, Z., Dai, S., Eds.; Royal Society of Chemistry: London, UK, 2014; pp. 111-139.

10. Andreeva, D.; Idakiev, V.; Tabakova, T.; Andreev, A.; Giovanoli, R. Low-temperature water-gas shift reaction on Au/alpha-Fe $\mathrm{O}_{3}$ catalyst. Appl. Catal. A Gen. 1996, 134, 275-283. [CrossRef]

11. Boccuzzi, F.; Chiorino, A.; Manzoli, M.; Andreeva, D.; Tabakova, T. FTIR study of the low-temperature water-gas shift reaction on $\mathrm{Au} / \mathrm{Fe}_{2} \mathrm{O}_{3}$ and $\mathrm{Au} / \mathrm{TiO}_{2}$ catalysts. J. Catal. 1999, 188, 176-185. [CrossRef]

12. Bunluesin, T.; Gorte, R.J.; Graham, G.W. Studies of the water-gas-shift reaction on ceria-supported Pt, Pd, and Rh: Implications for oxygen-storage properties. Appl. Catal. B Environ. 1998, 15, 107-114. [CrossRef]

13. Li, Y.; Fu, Q.; Flytzani-Stephanopoulos, M. Low-temperature water-gas shift reaction over Cu- and Ni-loaded cerium oxide catalysts. Appl. Catal. B Environ. 2000, 27, 179-191. [CrossRef]

14. Wang, X.Q.; Rodriguez, J.A.; Hanson, J.C.; Gamarra, D.; Martinez-Arias, A.; Fernandez-Garcia, M. In situ studies of the active sites for the water gas shift reaction over $\mathrm{Cu}-\mathrm{CeO}_{2}$ catalysts: Complex interaction between metallic copper and oxygen vacancies of ceria. J. Phys. Chem. B 2006, 110, 428-434. [CrossRef] [PubMed] 
15. Wang, X.; Gorte, R.J. The effect of Fe and other promoters on the activity of Pd/ceria for the water-gas shift reaction. Appl. Catal. A Gen. 2003, 247, 157-162. [CrossRef]

16. Fu, Q.; Weber, A.; Flytzani-Stephanopoulos, M. Nanostructured $\mathrm{Au}-\mathrm{CeO}_{2}$ catalysts for low-temperature water-gas shift. Catal. Lett. 2001, 77, 87-95. [CrossRef]

17. Karpenko, A.; Leppelt, R.; Cai, J.; Plzak, V.; Chuvilin, A.; Kaiser, U.; Behm, R.J. Deactivation of a $\mathrm{Au} / \mathrm{CeO}_{2}$ catalyst during the low-temperature water-gas shift reaction and its reactivation: A combined TEM, XRD, XPS, DRIFTS, and activity study. J. Catal. 2007, 250, 139-150. [CrossRef]

18. Andreeva, D. Low temperature water gas shift over gold catalysts. Gold Bull. 2002, 35, 82-88. [CrossRef]

19. Abdel-Mageed, A.M.; Kučerová, G.; Bansmann, J.; Behm, R.J. Active Au Species During the Low-Temperature Water Gas Shift Reaction on $\mathrm{Au} / \mathrm{CeO}_{2}$ : A Time-Resolved Operando XAS and DRIFTS Study. ACS Catal. 2017, 7, 6471-6484. [CrossRef]

20. Tibiletti, D.; Amieiro-Fonseca, A.; Burch, R.; Chen, Y.; Fisher, J.M.; Goguet, A.; Hardacre, C.; Hu, P.; Thompsett, A. DFT and in situ EXAFS investigation of gold/ceria-zirconia low-temperature water gas shift catalysts: Identification of the nature of the active form of gold. J. Phys. Chem. B 2005, 109, 22553-22559. [CrossRef]

21. Goguet, A.; Burch, R.; Chen, Y.; Hardacre, C.; Hu, P.; Joyner, R.W.; Meunier, F.C.; Mun, B.S.; Thompsett, A.; Tibiletti, D. Deactivation mechanism of a $\mathrm{Au} / \mathrm{CeZrO}_{4}$ catalyst during a low-temperature water gas shift reaction. J. Phys. Chem. C 2007, 111, 16927-16933. [CrossRef]

22. Daly, H.; Goguet, A.; Hardacre, C.; Meunier, F.C.; Pilasombat, R.; Thompsett, D. The effect of reaction conditions on the stability of $\mathrm{Au} / \mathrm{CeZrO}$ catalysts in the low-temperature water-gas shift reaction. J. Catal. 2010, 273, 257-265. [CrossRef]

23. Carter, J.; Liu, X.; He, Q.; Althahban, S.; Nowicka, E.; Freakley, S.; Niu, L.; Morgan, D.; Li, Y.; Niemantsverdriet, H.; et al. Activation and Deactivation of gold/ceria-zirconia in the Low-Temperature Water-Gas Shift Reaction. Angew. Chem. Int. Ed. 2017, 56, 16037-16041. [CrossRef] [PubMed]

24. Stere, C.E.; Anderson, J.A.; Chansai, S.; Delgado, J.J.; Goguet, A.; Graham, W.G.; Hardacre, C.; Taylor, S.F.R.; Tu, X.; Wang, Z.Y.; et al. Non-Thermal Plasma Activation of Gold-Based Catalysts for Low-Temperature Water-Gas Shift Catalysis. Angew. Chem. Int. Ed. 2017, 56, 5579-5583. [CrossRef] [PubMed]

25. Malta, G.; Kondrat, S.A.; Freakley, S.J.; Davies, C.J.; Lu, L.; Dawson, S.; Thetford, A.; Gibson, E.K.; Morgan, D.J.; Jones, W.; et al. Identification of single-site gold catalysis in acetylene hydrochlorination. Science 2017, 355, 1399-1402. [CrossRef] [PubMed]

26. Andreeva, D.; Ivanov, I.; Ilieva, L.; Sobczak, J.W.; Avdeev, G.; Tabakova, T. Nanosized gold catalysts supported on ceria and ceria-alumina for WGS reaction: Influence of the preparation method. Appl. Catal. A Gen. 2007, 333, 153-160. [CrossRef]

27. Andreeva, D.; Ivanova, I.; Ilieva, L.; Abrashev, M.V. Gold catalysts supported on ceria and ceria-alumina for water-gas shift reaction. Appl. Catal. A Gen. 2006, 302, 127-132. [CrossRef]

28. Reina, T.R.; Ivanova, S.; Centeno, M.A.; Odriozola, J.A. Boosting the activity of a $\mathrm{Au} / \mathrm{CeO}_{2} / \mathrm{Al}_{2} \mathrm{O}_{3}$ catalyst for the WGS reaction. Catal. Today 2015, 253, 149-154. [CrossRef]

29. Reina, T.R.; Xu, W.Q.; Ivanova, S.; Centeno, M.A.; Hanson, J.; Rodriguez, J.A.; Odriozola, J.A. In situ characterization of iron-promoted ceria-alumina gold catalysts during the water-gas shift reaction. Catal. Today 2013, 205, 41-48. [CrossRef]

30. Andreeva, D.; Kantcheva, M.; Ivanov, I.; Ilieva, L.; Sobczak, J.W.; Lisowski, W. Gold supported on ceria doped by $\mathrm{Me}^{3+}(\mathrm{Me}=\mathrm{Al}$ and $\mathrm{Sm})$ for water gas shift reaction: Influence of dopant and preparation method. Catal. Today 2010, 158, 69-77. [CrossRef]

31. Andreeva, D.; Ivanov, I.; Ilieva, L.; Abrashev, M.V.; Zanella, R.; Sobczak, J.W.; Lisowski, W.; Kantcheva, M.; Avdeev, G.; Petrov, K. Gold catalysts supported on ceria doped by rare earth metals for water gas shift reaction: Influence of the preparation method. Appl. Catal. A Gen. 2009, 357, 159-169. [CrossRef]

32. Vecchietti, J.; Collins, S.; Jose Delgado, J.; Malecka, M.; del Rio, E.; Chen, X.; Bernal, S.; Bonivardi, A. Gold Catalysts Supported on Cerium-Gallium Mixed Oxide for the Carbon Monoxide Oxidation and Water Gas Shift Reaction. Top. Catal. 2011, 54, 201-209. [CrossRef]

33. Tabakova, T.; Ilieva, L.; Ivanov, I.; Zanella, R.; Sobczak, J.W.; Lisowski, W.; Kaszkur, Z.; Andreeva, D. Influence of the preparation method and dopants nature on the WGS activity of gold catalysts supported on doped by transition metals ceria. Appl. Catal. B Environ. 2013, 136, 70-80. [CrossRef] 
34. Kondrat, S.A.; Smith, P.J.; Wells, P.P.; Chater, P.A.; Carter, J.H.; Morgan, D.J.; Fiordaliso, E.M.; Wagner, J.B.; Davies, T.E.; Lu, L.; et al. Stable amorphous georgeite as a precursor to a high-activity catalyst. Nature 2016, 531, 83-87. [CrossRef] [PubMed]

35. Santos, J.L.; Reina, T.R.; Ivanov, I.; Penkova, A.; Ivanova, S.; Tabakova, T.; Centeno, M.A.; Idakiev, V.; Odriozola, J.A. Multicomponent $\mathrm{Au} / \mathrm{Cu}-\mathrm{ZnO}-\mathrm{Al}_{2} \mathrm{O}_{3}$ catalysts: Robust materials for clean hydrogen production. Appl. Catal. A Gen. 2018, 558, 91-98. [CrossRef]

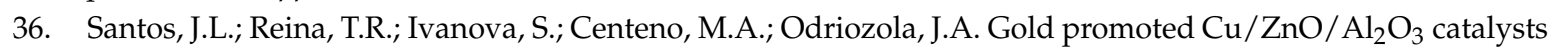
prepared from hydrotalcite precursors: Advanced materials for the WGS reaction. Appl. Catal. B Environ. 2017, 201, 310-317. [CrossRef]

37. Reina, T.R.; Ivanova, S.; Centeno, M.A.; Odriozola, J.A. The role of $\mathrm{Au}, \mathrm{Cu} \& \mathrm{CeO}_{2}$ and their interactions for an enhanced WGS performance. Appl. Catal. B Environ. 2016, 187, 98-107. [CrossRef]

38. Si, R.; Flytzani-Stephanopoulos, M. Shape and crystal-plane effects of nanoscale ceria on the activity of $\mathrm{Au}-\mathrm{CeO}_{2}$ catalysts for the water-gas shift reaction. Angew. Chem. Int. Ed. 2008, 47, 2884-2887. [CrossRef]

39. Ta, N.; Liu, J.; Chenna, S.; Crozier, P.A.; Li, Y.; Chen, A.; Shen, W. Stabilized Gold Nanoparticles on Ceria Nanorods by Strong Interfacial Anchoring. J. Am. Chem. Soc. 2012, 134, 20585-20588. [CrossRef]

40. Yuan, Z.-Y.; Idakiev, V.; Vantomme, A.; Tabakova, T.; Ren, T.-Z.; Su, B.-L. Mesoporous and nanostructured $\mathrm{CeO}_{2}$ as supports of nano-sized gold catalysts for low-temperature water-gas shift reaction. Catal. Today 2008, 131, 203-210. [CrossRef]

41. Flytzani-Stephanopoulos, M. Gold Atoms Stabilized on Various Supports Catalyze the Water-Gas Shift Reaction. Accounts Chem. Res. 2014, 47, 783-792. [CrossRef]

42. Sandoval, A.; Gomez-Cortes, A.; Zanella, R.; Diaz, G.; Saniger, J.M. Gold nanoparticles: Support effects for the WGS reaction. J. Mol. Catal. A Chem. 2007, 278, 200-208. [CrossRef]

43. Shekhar, M.; Wang, J.; Lee, W.S.; Williams, W.D.; Kim, S.M.; Stach, E.A.; Miller, J.T.; Delgass, W.N.; Ribeiro, F.H. Size and Support Effects for the Water-Gas Shift Catalysis over Gold Nanoparticles Supported on Model $\mathrm{Al}_{2} \mathrm{O}_{3}$ and $\mathrm{TiO}_{2}$. J. Am. Chem. Soc. 2012, 134, 4700-4708. [CrossRef] [PubMed]

44. Gil, S.; Romero, A.; de Lucas, A.; Sanchez, P.; Dorado, F.; Raquel de la Osa, A.; Manuel Garcia-Vargas, J.; Luis Valverde, J. Nano-Scale Au Supported on Carbon Materials for the Low Temperature Water Gas Shift (WGS) Reaction. Catalysts 2011, 1, 155-174. [CrossRef]

45. Yang, M.; Li, S.; Wang, Y.; Herron, J.A.; Xu, Y.; Allard, L.F.; Lee, S.; Huang, J.; Mavrikakis, M.; Flytzani-Stephanopoulos, M. Catalytically active $\mathrm{Au}-\mathrm{O}(\mathrm{OH})(\mathrm{x})$-species stabilized by alkali ions on zeolites and mesoporous oxides. Science 2014, 346, 1498-1501. [CrossRef] [PubMed]

46. Ma, Y.F.; Guan, G.Q.; Hao, X.G.; Cao, J.; Abudula, A. Molybdenum carbide as alternative catalyst for hydrogen production-A review. Renew. Sustain. Energy Rev. 2017, 75, 1101-1129. [CrossRef]

47. Liu, P.; Rodriguez, J.A. Water-gas-shift reaction on molybdenum carbide surfaces: Essential role of the oxycarbide. J. Phys. Chem. B 2006, 110, 19418-19425. [CrossRef]

48. Patt, J.; Moon, D.J.; Phillips, C.; Thompson, L. Molybdenum carbide catalysts for water-gas shift. Catal. Lett. 2000, 65, 193-195. [CrossRef]

49. Dong, J.; Fu, Q.; Jiang, Z.; Mei, B.; Bao, X. Carbide-Supported Au Catalysts for Water-Gas Shift Reactions: A New Territory for the Strong Metal-Support Interaction Effect. J. Am. Chem. Soc. 2018, 140, 13808-13816. [CrossRef]

50. Tang, H.L.; Su, Y.; Zhang, B.S.; Lee, A.F.; Isaacs, M.A.; Wilson, K.; Li, L.; Ren, Y.G.; Huang, J.H.; Haruta, M.; et al. Classical strong metal-support interactions between gold nanoparticles and titanium dioxide. Sci. Adv. 2017, 3, e1700231. [CrossRef]

51. Fu, Q.; Wagner, T.; Olliges, S.; Carstanjen, H.D. Metal-oxide interfacial reactions: Encapsulation of Pd on $\mathrm{TiO}_{2}$ (110). J. Phys. Chem. B 2005, 109, 944-951. [CrossRef]

52. Song, L.; Cao, X.; Li, L. Engineering Stable Surface Oxygen Vacancies on $\mathrm{ZrO}_{2}$ by Hydrogen-Etching Technology: An Efficient Support of Gold Catalysts for Water-Gas Shift Reaction. ACS Appl. Mater. Interfaces 2018, 10, 31249-31259. [CrossRef] [PubMed]

53. Li, L.; Song, L.; Zhu, L.F.; Yan, Z.; Cao, X.B. Black $\mathrm{TiO}_{2}-\mathrm{x}$ with stable surface oxygen vacancies as the support of efficient gold catalysts for water-gas shift reaction. Catal. Sci. Technol. 2018, 8, 1277-1287. [CrossRef]

54. Song, L.; Lu, Z.F.; Zhang, Y.T.; Su, Q.; Li, L. Hydrogen-Etched $\mathrm{TiO}_{2}-\mathrm{x}$ as Efficient Support of Gold Catalysts for Water-Gas Shift Reaction. Catalysts 2018, 8, 26. [CrossRef] 
55. Kesavan, L.; Tiruvalam, R.; Ab Rahim, M.H.; bin Saiman, M.I.; Enache, D.I.; Jenkins, R.L.; Dimitratos, N.; Lopez-Sanchez, J.A.; Taylor, S.H.; Knight, D.W.; et al. Solvent-Free Oxidation of Primary Carbon-Hydrogen Bonds in Toluene Using Au-Pd Alloy Nanoparticles. Science 2011, 331, 195-199. [CrossRef] [PubMed]

56. Ab Rahim, M.H.; Forde, M.M.; Jenkins, R.L.; Hammond, C.; He, Q.; Dimitratos, N.; Lopez-Sanchez, J.A.; Carley, A.F.; Taylor, S.H.; Willock, D.J.; et al. Oxidation of Methane to Methanol with Hydrogen Peroxide Using Supported Gold-Palladium Alloy Nanoparticles. Angew. Chem. Int. Ed. 2013, 52, 1280-1284. [CrossRef] [PubMed]

57. Sankar, M.; Nowicka, E.; Tiruvalam, R.; He, Q.; Taylor, S.H.; Kiely, C.J.; Bethell, D.; Knight, D.W.; Hutchings, G.J. Controlling the Duality of the Mechanism in Liquid-Phase Oxidation of Benzyl Alcohol Catalysed by Supported Au-Pd Nanoparticles. Chem. A Eur. J. 2011, 17, 6524-6532. [CrossRef] [PubMed]

58. Venugopal, A.; Aluha, J.; Scurrell, M.S. The water-gas shift reaction over Au-based, bimetallic catalysts. The Au-M (M = Ag, Bi, Co, Cu, Mn, Ni, Pb, Ru, Sn, Tl) on iron(III) oxide system. Catal. Lett. 2003, 90, 1-6. [CrossRef]

59. Venugopal, A.; Aluha, J.; Mogano, D.; Scurrell, M.S. The gold-ruthenium-iron oxide catalytic system for the low temperature water-gas-shift reaction-The examination of gold-ruthenium interactions. Appl. Catal. A Gen. 2003, 245, 149-158. [CrossRef]

60. Hurtado-Juan, M.-A.; Yeung, C.M.Y.; Tsang, S.C. A study of co-precipitated bimetallic gold catalysts for water-gas shift reaction. Catal. Commun. 2008, 9, 1551-1557. [CrossRef]

61. Burch, R.; Goguet, A.; Meunier, F.C. A critical analysis of the experimental evidence for and against a formate mechanism for high activity water-gas shift catalysts. Appl. Catal. A Gen. 2011, 409, 3-12. [CrossRef]

62. Castano, M.G.; Reina, T.R.; Ivanova, S.; Centeno, M.A.; Odriozola, J.A. Pt vs. Au in water-gas shift reaction. J. Catal. 2014, 314, 1-9. [CrossRef]

63. Carter, J.H.; Althahban, S.; Nowicka, E.; Freakley, S.J.; Morgan, D.J.; Shah, P.M.; Golunski, S.; Kiely, C.J.; Hutchings, G.J. Synergy and Anti-Synergy between Palladium and Gold in Nanoparticles Dispersed on a Reducible Support. ACS Catal. 2016, 6, 6623-6633. [CrossRef] [PubMed]

64. Gibson, E.K.; Beale, A.M.; Catlow, C.R.A.; Chutia, A.; Gianolio, D.; Gould, A.; Kroner, A.; Mohammed, K.M.H.; Perdjon, M.; Rogers, S.M.; et al. Restructuring of AuPd Nanoparticles Studied by a Combined XAFS/DRIFTS Approach. Chem. Mater. 2015, 27, 3714-3720. [CrossRef]

65. Zhu, B.; Thrimurthulu, G.; Delannoy, L.; Louis, C.; Mottet, C.; Creuze, J.; Legrand, B.; Guesmi, H. Evidence of Pd segregation and stabilization at edges of AuPd nano-clusters in the presence of CO: A combined DFT and DRIFTS study. J. Catal. 2013, 308, 272-281. [CrossRef]

66. Saqlain, M.A.; Hussain, A.; Siddiq, M.; Leitao, A.A. Synergy between Pd and Au in a Pd-Au(100) bimetallic surface for the water gas shift reaction: A DFT study. RSC Adv. 2015, 5, 47066-47073. [CrossRef]

67. Rodriguez, J.A. Gold-based catalysts for the water-gas shift reaction: Active sites and reaction mechanism. Catal. Today 2011, 160, 3-10. [CrossRef]

68. Bond, G. Mechanisms of the gold-catalysed water-gas shift. Gold Bull. 2009, 42, 337-342. [CrossRef]

69. Tao, F.; Ma, Z. Water-gas shift on gold catalysts: Catalyst systems and fundamental studies. Phys. Chem. Chem. Phys. 2013, 15, 15260-15270. [CrossRef] [PubMed]

70. Tabakova, T.; Boccuzzi, F.; Manzoli, M.; Sobczak, J.W.; Idakiev, V.; Andreeva, D. A comparative study of nanosized IB/ceria catalysts for low-temperature water-gas shift reaction. Appl. Catal. A Gen. 2006, 298, 127-143. [CrossRef]

71. Burch, R. Gold catalysts for pure hydrogen production in the water-gas shift reaction: Activity, structure and reaction mechanism. Phys. Chem. Chem. Phys. 2006, 8, 5483-5500. [CrossRef] [PubMed]

72. Sakurai, H.; Akita, T.; Tsubota, S.; Kiuchi, M.; Haruta, M. Low-temperature activity of $\mathrm{Au} / \mathrm{CeO}_{2}$ for water gas shift reaction, and characterization by ADF-STEM, temperature-programmed reaction, and pulse reaction. Appl. Catal. A Gen. 2005, 291, 179-187. [CrossRef]

73. Jacobs, G.; Chenu, E.; Patterson, P.M.; Williams, L.; Sparks, D.; Thomas, G.; Davis, B.H. Water-gas shift: Comparative screening of metal promoters for metal/ceria systems and role of the metal. Appl. Catal. A Gen. 2004, 258, 203-214. [CrossRef]

74. Leppelt, R.; Schumacher, B.; Plzak, V.; Kinne, M.; Behm, R.J. Kinetics and mechanism of the low-temperature water-gas shift reaction on $\mathrm{Au} / \mathrm{CeO}_{2}$ catalysts in an idealized reaction atmosphere. J. Catal. 2006, 244, 137-152. [CrossRef] 
75. Meunier, F.C.; Reid, D.; Goguet, A.; Shekhtman, S.; Hardacre, C.; Burch, R.; Deng, W.; Flytzani-Stephanopoulos, M. Quantitative analysis of the reactivity of formate species seen by DRIFTS over a $\mathrm{Au} / \mathrm{Ce}(\mathrm{La}) \mathrm{O}-2$ water-gas shift catalyst: First unambiguous evidence of the minority role of formates as reaction intermediates. J. Catal. 2007, 247, 277-287. [CrossRef]

76. Jacobs, G.; Patterson, P.M.; Graham, U.M.; Crawford, A.C.; Davis, B.H. Low temperature water gas shift: The link between the catalysis of WGS and formic acid decomposition over Pt/ceria. Int. J. Hydrogen Energy 2005, 30, 1265-1276. [CrossRef]

77. Rodriguez, J.A.; Senanayake, S.D.; Stacchiola, D.; Liu, P.; Hrbek, J. The Activation of Gold and the Water-Gas Shift Reaction: Insights from Studies with Model Catalysts. Accounts Chem. Res. 2014, 47, 773-782. [CrossRef] [PubMed]

78. Liu, N.Y.; Guo, L.; Cao, Z.R.; Li, A.X.; An, X.Y. Density functional theory study of water-gas shift reaction on TM@Cu-12 core-shell nanoclusters. Prot. Met. Phys. Chem. Surf. 2016, 52, 387-398. [CrossRef]

79. Saqlain, M.A.; Hussain, A.; Siddiq, M.; Leenaerts, O.; Leitao, A.A. DFT Study of Synergistic Catalysis of the Water-Gas-Shift Reaction on Cu-Au Bimetallic Surfaces. Chemcatchem 2016, 8, 1208-1217. [CrossRef]

(C) 2018 by the authors. Licensee MDPI, Basel, Switzerland. This article is an open access article distributed under the terms and conditions of the Creative Commons Attribution (CC BY) license (http:/ / creativecommons.org/licenses/by/4.0/). 